\section{ECONOMICS

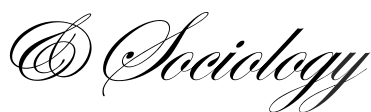

Ina Lodewyckx

Centre for Migration and

Intercultural Studies (CeMIS),

University of Antwerp

Christiane Timmerman

Centre for Migration and

Intercultural Studies (CeMIS),

University of Antwerp

Johan Wets

Higher Institute for Labour Studies (HIV A), Catholique University of

Louvain

Received: June, 2010

1st Revision: September, 2010

Accepted: October, 2010

JEL Classification: F22, P1
Ina Lodewyckx, Christiane Timmerman, Johan Wets, From Nation State to Migration State, Economics \& Sociology, Vol. 3, No 2, 2010, pp. 9-22.

\title{
FROM NATION STATE TO MIGRATION STATE
}

\begin{abstract}
International migration and its consequences - the integration of newcomers to a society - has, in just a few years' time, developed from a purely demographic phenomenon into an issue that has altered the 'being' of the Western Nation-state in all its facets. The topic largely dominates the political debate in Flanders, Belgium and at the level of the European Union.
\end{abstract}

Keywords: international migration, 'multicultural society', Western Nation-state.

\section{Introduction}

Large-scale unwanted migration is regarded as a threat, both in the public opinion and within international forums. In the same context, the topic of the 'multicultural society' is increasingly the focus of attention. One aspect missing in the debate is the recognition that living together with 'Others' - who do not necessarily share our values and principles - is an essential part of the democracy issue (Van den Bossche \& Zemni, 2002).

Immigration in Belgium, particularly by non-European migrants, changes the composition of society. A large influx of people of a different complexion and with other customs and values, who speak a different language and adhere to another religion, creates a new dynamic in society as a whole, but also within the immigrant community. Foreigners participate in society and undergo processes of integration and assimilation. They become politically more visible, and at the same time they increasingly disappear from the official statistics as foreigners as more and more people from ethnic minority communities acquire Belgian nationality.

These observations give rise to the following questions: is the concept of the "nationstate" sustainable in this day and age or are there perhaps other notions, such as that of multiple citizenship, that correspond more closely to the present reality? Who or what agency determines citizenship? How long does a foreigner stay foreign? In sum, how can principles such as the right to cultural diversity and the basic assumption of the 'Western' nation-state be combined within a society while retaining an adequate basis for social cohesion?

On the basis of answers to such questions, one can begin to formulate a societal model. Are models such as the American melting-pot model (which has meanwhile been replaced with the salad bowl) workable? Does the Canadian model of the multicultural 


\section{GUEST EDITORIAL}

society (which is also increasingly contested) offer a more viable alternative? Or is there perhaps a need for a specifically European model for the 21 st century?

\section{The current West European societal model}

\subsection{From nation-state to a liberal rule of law}

The West European societal model can be characterized by four processes: the forming of nation states, the secularisation process, the institutionalisation of life strands, also called 'pillarisation' (such as Christianity, socialism and liberalism) and the liberal rule of law.

Principle of the nation-state - In the course of the twentieth century, the rules for a liberal, constitutional welfare state were institutionalised within the West European nationstate. The entailed right to societal participation and solidarity between citizens may be regarded as the collective goods of the nation, whose application is guaranteed by the state. The nation-state may be interpreted as the outcome of a successful compromise between the interests of various social groups: the guarantee of political loyalty in return for social participation and security (Wimmer, 1997). Unlike in the multicultural empires of the past (e.g. the Hapsburg empire, the Ottoman Empire or Russia), the bureaucracy of the nation-state and the bureaucratic process were 'homogenised': access was restricted to the members of the nation-state. Although the majority of European nation-states were, from the beginning, multicultural in nature, it was assumed that the citizens of a state should ideally constitute a nation (Eller, 1999). All nation-states have tried to demonstrate that the territory on which their sovereignty applies is a natural entity encompassing a single people, a single feeling, and a single set of rules (laws). Such an 'inwardly' homogenising trend is, for example, noticeable in the histories of France, Italy and even Belgium, where local identities, languages, customs and moors were repressed and/or erased.

Secularisation - Another essential development to have unfolded in Europe in recent centuries is the gradual secularisation of society. Religion and the state have, over time, become detached. This is not so much a matter of a privatisation of religion and faith (see among others Berger, 1974 and 1992; Luckmann, 1967) as it is an aspect of a broader process of functional differentiation. Religion is no longer the all-encompassing explanatory framework, and has thus lost its grip on science, economics, education and politics. It has been superseded by specific systems for each of these societal domains. For religion, now reduced to one of many subsystems, the function remains of ultimate belief systems in a secularised environment (see also Laermans, 1996).

'Pillarisation' and its consequences for the nation-state - One of the most remarkable responses to this process of secularisation, at least in the Netherlands and in Belgium, was the 'pillarisation' of society. This term refers to the vertical division into own networks of provisions (ranging from political parties to holiday accommodations) at the community's expense. From the beginning, the relationship between the various pillars and the nation-state in which they function has been ambiguous. On the one hand, they reduce the identification of individual citizens with the nation-state; it is replaced with a sense of belonging to a particular catholic, socialist or liberal group. On the other, they enhance the social cohesion of the nation-state. This happens in various ways, the most striking of which is that individuals are replaced with the pillar and its associations as the unit of social solidarity. Certainly in relation to political decision-making and binding agreements this has proven a solid foundation for, among others, the emergence of the welfare state. Both developments - the fundamental undercurrent of secularisation and the visible response of pillarisation - are of great significance to the future of the western societal concept. The necessary integration of 


\section{GUEST EDITORIAL}

large communities that have not experienced this process of secularisation in the same way will lead to a constant exploration of the boundaries of what is possible and sustainable. At the same time, the phenomenon of pillarisation at least provides a solution, albeit a partial one, for those dimensions of life that may be organised in the semi-public sphere, i.e. public obligations (e.g. compulsory education) which can be fulfilled through own institutions (e.g. own school network) (Timmerman, 2003).

Growing cultural, ideological, linguistic and religious diversity have all contributed to the nineteenth-century concept of the western nation-state being called into question. With the rise of the transnational discourse, debates on citizenship, identity, participation and rights of ethnic minority citizens can no longer be regarded as a strictly national matter. The emergence and expansion of the European Union is a case in point. EU citizenship and regional as well as local identities, coupled with collective rights and cultural autonomy, have severed the ties of loyalty with a single nation. After all, the European Union makes it very clear that the various member states no longer possess a monopoly on sovereignty. Sovereignty has been distributed over local, national and transnational political institutions (Nuhoglu-Soysal, 1997).

Towards a liberal rule of law - It is clear that the various internal and external societal processes are changing the composition of society. External processes such as globalisation and growing immigration (especially of non-European migrants) and internal processes such as growing individualism, postmodernism, greater emphasis on free choice, empowerment, eclecticism, tolerance, secularisation and de-pillarisation have eroded the notion of the nationstate, and have compelled us to search for other concepts that correspond more closely to present-day reality.

A pluralistic, liberal rule of law could serve as a starting point. Unlike the notion of the nation-state, a liberal rule of law need not have such a homogenising effect in respect of culture and identity. As a political framework, it may encompass various identities, as long as everyone is able to identify with the constitution and with the principles of democratic decision-making. The multicultural society always exists within the rule of law, and the rule of law invariably has precedence over the multicultural society. Under a liberal rule of law, the key principles are: democracy, separation of church and state, equality for all, religious freedom... The neutrality that the liberal rule of law adopts vis-à-vis the various denominations and belief systems need not result in a notion of a neutral public arena where all symbols that refer to a religion or identity must be banned. Its neutrality may also be interpreted in a pluralist manner. The liberal rule of law (in the politico-philosophical rather than in the merely political sense) aims at providing a guarantee that people could (within certain margins) adhere to different beliefs and, in this manner, it strives to protect pluralism. This is achieved by, for example, the proclamation of certain basic individual rights, the separation of church and state and the separation of the public and the private spheres. The public authorities adopt a neutral position with regard to the various perspectives that people have on what is a 'good life'. They do not determine what is good or bad, but rather create a just framework in which people are able to experience their own way of life, culture, religion and personal identity. In other words, the liberal rule of law and the pluralism which it implies provide a framework for the integration of foreign and indigenous population groups, as well as a growing diversity. The question remains, however, whether this polity offers enough guarantees for the necessary cohesion in order to allow a society to function adequately.

\subsection{Access to the state}

Although Belgian society is today evolving towards a liberal rule of law system, membership of the nation, and thus right of residence and citizenship, are still determined first 


\section{GUEST EDITORIAL}

and foremost by the principle of descent. The introduction of the 'fast-track nationality law' has, however, slightly toned down that principle.

Immigration by non-nationals is, in this context, regarded more as an exception that needs to be taken care of by the state. The state has the right and even the duty to regulate the immigration of non-nationals through a system of admittance and rejection. The key questions in this respect are: Who should be admitted and who not? And under which conditions can non-nationals be allowed into the country? Immigrants' right to residence is then made dependent upon the rules and regulations under the prevailing policy of the state in question. And apparently, the content of such rules and regulations is determined largely by cyclical factors and ad-hoc measures rather than by a long-term view that takes into account the position of the state in its regional and broader international setting.

Generally speaking, there are two criteria for belonging to a state, so that in this respect we may distinguish between two types of national identity. First, there is the tradition of ius sanguinis, i.e. blood relationship, a collective genealogy based on a long historical memory (Diner, 1998). This corresponds with the ethnic model of national identity. Second, there is the tradition of ius soli, which ignores origin and ethnicity and connects membership of a state with institutions. To have been born on national soil is, in a sense, seen to neutralise all earlier attributes of belonging and memory. We could speak here of a civic model of national identity. This principle refers to a common territory, a community of laws and political institutions, and a minimum of shared values. Ius soli is concerned with the present, in the sense that it is about an exercise of the will by citizens to belong to a particular state. Ius sanguinis, on the other hand, refers to the past, in the sense that belonging to a state is legitimised exclusively on the basis of an attributed personal history (descent). (Diner, 1998; Hjerm, 1998).

National identity is described as a consciousness of a connection with the nation which gives people a sense of who they are, in relationship to others, and at the same time sets them a goal as a result of which they feel 'at home'. It is not so easy to define what this national identity is precisely. It is for example, quite clear that to meet certain formal requirements of Belgian citizenship does not suffice to be recognised as a "real" Belgian or Fleming and to become part of the imagined Belgian or Flemish community. One notices for example that it is commonly taken for granted in debates on migration, asylum seekers, illegal aliens, integration, citizenship, etc that there is such a thing as a 'Flemish' or a 'Belgian' identity to which 'others' (asylum seekers, migrants, Muslims, illegal aliens, newcomers, people from ethnic minorities, and new Belgians...) cannot (yet?) lay claim. "They" must therefore meet certain criteria before being able to benefit from the same rights and duties as natives. This identity is, however, experienced primarily subconsciously, and thus it remains undefined. It is not immediately clear which 'common values' we share and which rules newcomers in our society should adhere to. The dissociation between the formal criteria for the acquisition of Belgian citizenship as well as the implicit, often emotional, conditions to be recognised as a "Belgian" and a "Fleming" is illustrative of the complexity and multidimensionality of the concept of "national identity'.

The notion of 'primordial autochthony', as formulated by Roosens (1998), is particularly relevant in this context. It is a notion that determines more and more western societies. According to Roosens, this principle attributes special qualifications to individuals and groups in relation to a certain territory, because they are descendent from parents and forefathers who were 'the first' to have lived on this land. For this reason, it seems logical that autochthones are more entitled to be there than newcomers are (Timmerman, 2003). 


\section{GUEST EDITORIAL}

\subsection{Boundaries of the state}

In the previous paragraph, the countries of Western Europe were considered in the context of such notions as the nation-state and the liberal rule of law. Another characteristic of the West European societal model is the principle of the welfare state. One of the goals of the welfare state is to guarantee a minimum level of social security to its members. The basis for its functioning is the principle of mutual solidarity between citizens. The welfare state is a more or less closed system, in the sense that it is restricted to the members of the state and (save for certain exceptions) applies exclusively to a particular geographical area.

In the West European welfare states, we may distinguish between the boundary that regulates access to the territory and the boundary that is designed to protect access to the welfare state. The question that inevitably arises is whether newcomers should immediately be entitled to the same rights as residents, and which conditions they should fulfil to this end. It speaks for itself that there are qualitative restrictions to the level of welfare that the public authorities can guarantee to the citizens. There are also quantitative and associated geographical restrictions to take into account. Redistribution mechanism are only possible within a well-delineated community. Not only the notion of 'welfare' has boundaries, but so too has that of the 'state' (Entzinger, 1994). One of the aspects that a democratic welfare state must therefore control in order to protect and sustain itself is migration. Generally, the greater the tendency to consider collective accomplishments as holy ground, the smaller the willingness to extend solidarity to foreigners (Enzensberger, 1993).

Entzinger (1994) sees three possibilities: the egalitarian option, the minimal option and the dual option. In the first case, all people residing legally in the country are subject to the same set of rights and duties vis-à-vis the public authorities and the welfare state. This option combines the equality and the territoriality principles. No distinction is made between the indigenous population, ethnic minorities, newcomers and foreigners. The only relevant criterion is that the individual should be residing legally on the territory. Some of those arguing for more free migration at the same time recognise that the egalitarian option, whereby all are entitled to the same provisions as is presently the case, is not financially sustainable. Consequently, two possibilities impose themselves: either one chooses for the welfare state and therefore accepts that migration must be restricted and regulated, or one opts for freer migration, but then the social protection system will inevitably shrink. The more restrictive one's rules on access to the territory, the more flexible those governing access to the welfare state may be. But the reverse also holds true: the more flexible one's rules on access to the territory, the more restrictive an attitude one will need to adopt in relation to access to the prevailing welfare state provisions.

The second option is the minimal option. In this instance, social legislation is reduced considerably, albeit in an egalitarian manner. The welfare state provisions are cut for everyone, until an equal and feasible universal minimum is attained. This way, one evolves towards an ultraliberal state, where the redistribution mechanisms are reduced to an absolute minimum. This will lead to greater income inequality and starker contrasts in society, not in the least between foreigners and indigenous groups. This model is comparable to the American model: limited social provisions and a lot of room for employment.

Under the third, so-called dual option, social protection is only reduced for newcomers. Such a dual system actually institutionalises a kind of apartheid, as newcomers enjoy fewer rights than the rest of the population. From the perspective of the needs principle, one could legitimise such a differential system to a certain extent. After all, the present social minimums are based on a western lifestyle. Research has shown that the expectation patterns of immigrants from poorer countries are often lower, especially during the first years of 


\section{GUEST EDITORIAL}

migration. However, both options clash with the principles of equity and equality, which are after all so very characteristic of the European welfare state (Loobuyck, 2001a).

\subsection{The state and its citizens}

Concepts such as 'the citizen' and 'citizenship' have come to the fore in recent years in our society. Politicians, organisations and intellectuals are showing a growing tendency to approach societal problems from the perspective of citizenship. The notion of citizenship presupposes a system of mutual rights and duties between citizen and the public authorities. The reciprocity of this relationship is argued to encourage the citizen to participate more actively in politics and in public debates. However, the introduction of the notion also gave rise to the question: "Who is to be regarded as a citizen and who not?" After all, the aspect of participation in the public life of a society is associated immediately with the notions of inclusion and exclusion (Van den Bosche \& Zemni, 2002).

Citizenship as a legal status - In the Western European systems of a liberal rule of law, one starts from the concept of citizenship as a legal status. By this we mean that citizenship is regarded by law as a status that entitles individuals to rights vis-à-vis the state. One could argue that there are three types of categories (Marshall,1963). First and foremost, citizenship entails civil rights, civil liberties, which provide the individual with the bare minimum of protection. Examples that come to mind are protection against arbitrary detention, freedom of opinion and belief, the right to own property, the right to enter freely into contracts and the right to equality before the law. The next dimension concerns political rights that are designed to safeguard participation in political decision-making. A third dimension relates to social rights, intended to guarantee a minimum level of economic prosperity and social security in the (re)distribution of essential products and services.

In the context of citizenship as a legal status, the central question is: to what extent is an individual granted rights by the state (Jacobs, 2000)? The rights and duties that are associated with citizenship are indicative of a responsibility of the citizen towards society and vice versa. The term citizenship refers to the manner in which individuals interpret their relationship with the authorities as well as to the manner in which the authorities wish to treat individuals. The possibilities that people have to implement their rights and duties depend in part on the space that the authorities create to this end. The authorities must therefore provide guarantees with regard to the conditions for individual emancipation and participation. In a system of liberal rule of law, guaranteeing this basic accommodation is not incompatible with cultural pluralism. Special minority rights in support of the development of an own identity need not even be incompatible with the egalitarian liberal perspective (Loobuyck, 2000).

Within the approach of citizenship as a legal status, often a distinction is made between full formal membership of a nation - i.e. citizenship with full rights - and a partial form of membership, associated with limited rights (Stewart, 1995: 67). Full citizenship implies equal access to and participation in society, in terms of labour and various kinds of voluntary social relationships, as well as in relation to welfare state provisions in the fields of education and healthcare, and with regard to political policy (Loobuyck, 2003a). In the case of partial citizenship, it mainly concerns rights that foreigners are granted on the basis of their residence, i.e. the fact that they are officially registered as inhabitants of the country in question. Usually, they enjoy civil and social rights, but not political ones. With the arrival of migrants and the granting of certain rights to these foreigners (on the basis of residence rather than nationality), a gradation in formal citizenship has arisen. Certain rights, social goods and services are no longer reserved for nationals only, but are now extended to all those who are established residents within a certain territory. For example, in the wake of the emerging welfare state (Heisler \& Heisler, 1991), certain social and economic rights were attributed to 


\section{GUEST EDITORIAL}

immigrants, irrespective of nationality. In a subsequent stage, some countries also granted local political rights to foreigners. However, across Europe, full political rights remained reserved to nationals, on the basis of the principle of national sovereignty and the concern with the legitimacy of the nation-state. This gave rise to a situation where foreigners who had legally established themselves in the country were equal to nationals in almost all (legal) respects, except as far as political rights was concerned. In turn this led led to a form of 'partial citizenship' (Brubaker, 1990) whereby a distinction is made between fully-fledged 'citizens' (enjoying full rights) and 'denizens' (Hammar, 1990) (residents enjoying full rights, except political ones) (Jacobs, 2000).

\section{Policy models for the reception of newcomers}

\subsection{Some theoretical models}

Migration is not only a phenomenon of the recent and not-so-recent past, the effects of which we still feel today, but it is rather a reality that shall continue to challenge us in the future. In order to anticipate on this adequately, there is a need for an integrated immigration policy. It must be integrated, because migration is a complex issue that has consequences in various areas of society.

Given the growing diversity in our society, it is necessary for policymakers to consider how these new challenges can be translated into a sustainable societal model. After all, a degree of social cohesion is required in order for a state to be able to function properly. The question therefore arises how great a diversity a society can cope with without fragmenting into groups that increasingly withdraw into their own reality. Diversity and equality can be achieved in different ways within a state. In the literature, a wide range of policy models are put forward, but in this paper we restrict ourselves to a brief outline of four options: the segregation, the assimilation, the integration and the intercreative models.

Segregation means that a group of migrants is separated from the rest of society in one or several areas. In such a situation, it is easy to retain one's own culture. This process results in a society where different cultures live side by side. An extreme example was found in South Africa during Apartheid. Other examples are the presence of large groups of migrants in certain suburbs or inner city neighbourhoods or the manner in which certain groups of Orthodox Chasidic Jews manifest themselves in European society. The application of the segregation strategy as such says nothing about the socioeconomic position of the group in question (Loobuyck, 2003b).

Assimilation means that the minority adopts the social and cultural characteristics of the majority and is eventually absorbed entirely into the dominant culture. The result is a rather homogeneous society. This ideology rests on the assumption that a multicultural policy will lead to a disintegration and balkanisation of society (Loobuyck, 2003b).

In the cases of both segregation and assimilation, one needs to distinguish between imposed forms on the one hand and autosegregation or assimilation originating in the group that 'is to be assimilated' on the other.

A third policy option is the integration model. This we encounter in the activities of the various Belgian parliaments. Integration is participation in society without being set aside as a community (segregation) and without imposed conformism with the socio-cultural characteristics of the majority (assimilation). The official policies of most EU member states are based on the integration model (Loobuyck, 2003b; Kerkwerk multicultureel samenleven, 2001). 


\subsection{Policy options in the EU and Belgium}

Policy models in the EU - Most EU member states have officially opted for a policy of integration. The objective is said to be the inclusion of new population groups in society without them needing to abandon their cultural characteristics or being isolated from the majority'. In practice, however, the notion of integration is interpreted differently in different countries. There are substantial divergences in terms of attitudes towards minorities as well as their religious and cultural characteristics, and in relation to nationality and the possibility of participating in political decision-making. Generally speaking, two directions are distinguished: the British and Dutch model of multicultural society on the one hand and the French assimilation and adjustment policy on the other (Loobuyck, 2002). Most EU countries pursue policies that combine elements of the multicultural and the assimilation/adjustment models.

Integration policy in Belgium - With the establishment in 1989 of the Royal Commissariat for Migrant Policy (KCM), a start was made in Belgium with a specific policy on migrants, in which 'Integration' would become a key concept. Two aspects were taken into account: "1. The integration concept is based on the notion of 'adjustment', in accordance with the following criteria: a) assimilation, where the 'public order' so requires, b) consistent enhancement of the best possible adjustment in accordance with the basic social principles on which the culture of the guest country is founded and that are related to 'modernity', 'emancipation' and 'fully-fledged pluralism' - as understood in a modern western state, and c) unequivocal respect for the cultural diversity as a form of mutual enrichment in other fields. 2. Integration must go hand in hand with an enhancement of the structural involvement of minorities in the activities and goals of the public authorities"(KCM, 1989). Belgium's integration policy is represented by the public authorities and its champions as leaning towards a multicultural integration policy that leaves ample room for diversity and pluralism. Critics have labelled it an assimilation policy (Loobuyck, 2001b).

Pursuant to the special law of 8 August 1980, policymaking on the reception and integration of immigrants has been transferred to the Flemish Community, whereby competency has been assigned to the minister 'responsible for assistance to persons'. Since 1987, the Regions (employment) and Communities (education and cultural affairs) have formulated their own integration policies. In Wallonia, the approach is modelled primarily on the French assimilation policy, while the Flemish perspective tends more towards the British and Dutch integration policies (Vermeulen et al, 1997). Flanders' integration policy should be seen in the broader context of European (immigration policy), national (migrant-related policies such as nationality acquisition, voting rights) and regional policies. In the field of immigration policy, which is concerned with managing and regulating immigration, a convergence is noticeable at the European level between a number of treaties (such as the Treaty of Rome and the Treaty of Maastricht). In the field of migrant-related policy, this convergence is less visible, and national and regional differences continue to come into play. Within the Flemish integration policy, we observe a gradual shift from a collective notion of integration (with retention of the ethnic identity), whereby responsibility lies primarily with the guest society and the public authorities, to an individual notion of integration (citizenship and adjustment), whereby the responsibility lies mainly with the minorities themselves. Increasingly, voices are heard in favour of a more forceful approach to integration (Boender, 2001; Lodewyckx \& Geets, 2002). 


\section{Social cohesion and institutionalisation of social conflicts 1}

With the various migration streams and the present globalisation trend, there is no denying that contemporary Western European society is a multicultural society. Many inhabitants of the EU hold a foreign nationality or have (grand)parents of foreign descent (Loobuyck, 2003b). The presence of ethnic minorities has enhanced Europe's cultural diversity. A rather obvious example of this is found in our eating habits. Even in the smallest of Flemish towns one now finds restaurants serving 'foreign' food, and most shops now offer an array of exotic products. In the streets, one sees a greater variety of clothing styles and hears foreign-sounding names. Shops, cafés and meeting places with an unmistakably foreign atmosphere are increasingly a part of local life. Multicultural festivals and events are becoming more and more popular. We therefore tend to speak more easily of Flanders as a multicultural society. In the truest sense of the word, our society has been 'multicultural' since long before the immigration flows of the 1960s, as the "territory of Belgium" has always been a place where people of different nationalities, religions, sexual orientations, ideologies and socioeconomic backgrounds have cohabited. What is relatively new, though, is the great diversity in terms of ethnic origin.

The concept of 'the multicultural society' is associated with many aspects that are related only vaguely with culture. In the general Flemish discourse, 'multicultural society' is not equated with 'cultural enrichment', but is rather associated with a fear for material deprivation - i.e. the requirement of having to share with too many foreigners - and loss of the familiar. The familiar frame of reference is in danger of undergoing fundamental change. One also fears the social dominance of foreign communities in one's own neighbourhood.

For that matter, in day-to-day language, the phrase 'multicultural society' has many meanings. In a descriptive sense, it refers to a society made up of population groups from various origins and descent, and with divergent cultural traditions. However, the term is also used in a normative sense, as an ideal model. In this sense, the state concerned must offer institutional space to all ethnic and national groups that are established within its territory, it must recognise these groups, their culture and language, and invariably strive for equal rights (Roosens, 1998).

As far as the ethnic minorities are concerned, we see that their behaviour is, in many respects, driven by the same principles as the behaviour of Belgians is. They largely want the same consumption goods. They want to live comfortably and attribute great value to homeownership. A high income or a professional career are by no means rejected. Western medicine and social security are embraced wholeheartedly. Moroccan and Turkish parents generally also believe in the possibilities of social promotion that western education offers and they want their children to be able to benefit from it. For that matter, many Western ideas are adopted: when young Moroccans speak about equal rights or the right to retain their own religious or cultural identity, they tend to do so from a western universal perspective rather than from an Islamic point of view (Timmerman, 2003). In other words, ethnic minorities tend to adopt to the cultural praxis of the dominant culture to a much greater degree than may initially seem to be the case.

Despite the growing homogenisation of the socio-cultural praxis of migrants and the autochthonous population, ethnic identity continues to be important. It is a known phenomenon that, in an uncertain context such as a society in transition, people often have a greater need for structure, so that they tend to retreat into a space where they feel self-assured and protected. According to Ahmed (1995), individuals who find themselves in such a situation tend to fall back on their 'original' identity, which is defined in terms of 'tradition'

\footnotetext{
${ }^{1}$ With special thanks to Fernand Tanghe.
} 


\section{GUEST EDITORIAL}

and 'culture' and is often legitimised through descent. In other words, they seek an ethnic identity. In order to attribute a content to an ethnic identity, individuals often call on cultural elements which they believe distinguish them positively from others. Moreover, the cultural traits that one selects to legitimise the own ethnic identity will often vary over time and even depending on the context, without compromising the sense of continuity and belonging. Still, this does not exclude the possibility that the selected 'cultural emblems' may have a negative symbolic significance to outsiders - an example that springs to mind is the headscarf, which to many Muslims is an ethno-religious symbol. It is remarkable that what one has in common with the 'other' is rarely perceived as 'culture' (Roosens, 1998). Nevertheless, a careful analysis of the fundamental values of the various ethnic communities (foreign as well as autochthonous) points towards similarity rather than difference.

For the legitimisation of their own ethnic identity, people often refer to an assumed common origin and a shared historical experience. The accents that are laid are often codetermined by the present situation and there is rarely any solid historical truth to them. History is, after all, open to various interpretations. The manner in which one uses the past offers insight into the significance that one attributes to the present.

At the same time, in recent decades, the presence of a new 'cultural concept' has manifested itself prominently at a rational level. Among other things, as a reaction to the horrors of the holocaust, subsequently enhanced by a sense of shame for the destructive consequences of western colonialism, the idea has taken hold that every 'culture' is intrinsically valuable. It is assumed that cultures, at the level of their value systems, cannot be compared (Roosens, 1998).

As this 'cultural relativism' is formalised and promoted in the functioning of respected supranational institutions such as the United Nations, UNESCO and the Council of Europe, it has brought about essential change across the world. Consequently, the notion of the 'right to an own culture' has acquired political legitimacy and is now considered to be a specific type of human right. Private aspects of communities, such as culture, language and religion, are now recognised as variants to the universal core of human dignity and identity. Of central importance is the notion of 'the person', an abstract universal concept supported by legal, scientific and popular conventions for which the established 'Human Rights' provide a formal framework (Nuhoglu-Soysal, 1997). Various ethnic minority groups mobilise around a certain aspect of their identity which is perceived to be 'different' from that of 'others'. They demand that, in their 'being different', they be treated as equals to other citizens.

Ethnicity offers an opportunity to elude socioeconomic stratification. After all, the cultural relativist discourse creates a climate where all 'cultures' should be regarded to be equal. The cultural relativist perspective also offers people who occupy an unfavourable position in the social hierarchy the prospect of manifesting themselves as 'equals' on the basis of their cultural singularity. This way, one is given an opportunity to participate in a solidarity that is legitimised not by a national, but by a supranational discourse, and to thus transcend the precarious socioeconomic situation. Therefore, Eller (1999) rightly considers ethnic groups as a politicised version of cultural relativism.

However, some critical observations are in place here. There is a danger that by focusing primarily on phenomena such as identity and culture - e.g. the ongoing debate on the headscarf - one might lose sight of crucial socioeconomic aspects such as deprivation and exclusion. We must therefore ask ourselves whether multiculturalism, in the sense of a consecration of 'cultural identities', through the attribution of separate rights, might not lead to greater ghettoisation and a differentiated citizenship that is hard to reconcile with the notion of universal citizenship. In the last decade, we have seen that contacts between ethnic minority and indigenous groups increasingly often assume a confrontational and polarised quality. A growing number of ethnic minority and indigenous persons like to retreat into their 


\section{GUEST EDITORIAL}

'own' ethnic group and to cultivate the presumed difference as an excuse to decline any form of dialogue.

Should one not seek ways, within the de facto continuation of the nation-state, to arrive at mutual involvement on the part of the various 'resident' communities and groups, on the basis of shared values of an ethical-universal nature and a 'bridging' potential, rather than to emphasise particularised and coloured (ethnic, religious, etc.) values?

\section{Conclusion}

However, the above does not mean that democracy is synonymous with trouble-free social harmony, or that it implies ideological uniformity or unwavering consensus. Quite the contrary in fact, a democracy recognises that social and political conflicts are inevitable; it accepts them in practice and considers them as legitimate. At the same time, it offers procedures and rules of play through which conflicts can, including in the long-term, continue to exist and manifest themselves without a need for the virtual violence that lies enclosed in them to gain the upper hand and lead to destructive impasses. In this sense, noone has 'the last word' in a democracy. Democracy encourages everyone to 'have their say'. Thus, it is precisely because social and political conflicts are an essential characteristic of democracy that democracy expects all citizens to be involved in these conflicts in one way or another, and that they should perceive and feel that they are 'implied' in a never-ending debate on the definition and destination of their society. This is an objective as well as a subjective requirement: democracy organises this shared involvement of all its members and all strata of society, and at the same institutionalises the conflict. It implies that all should feel involved in the perpetual debate on the purpose and goals of 'their' society and thus, in one way or another, should side with one of the conflicting parties. In this manner, conflicts can, paradoxically, become a factor of social cohesion: the fighting parties manifest themselves, despite the diverging opinions and interests that divide them, as members of the same society. They are part of a world which, precisely because it is the subject of conflict and debate, is a shared world. The shared involvement in a conflict over society itself is an unmistakably pluralistic manner of meeting the requirement of social cohesion; at the same time it creates a mutual involvement of all members, without which no society could survive in the long term. This also means that democracy does not imply consensus or ideological uniformity, but rather a shared public opinion, in the sense that everyone is aware of the opinions and points of views of others and take those perspectives into account, however 'deviant' they may be. It also presupposes that the members and various groups of a society be aware at least to a certain extent of each other's problems and be willing to consider situations from the other's perspective, which obviously requires a degree of empathy. This is indeed at the heart of the organisation of our complex contemporary society. Hannerz (1992), for example, asserts that there is a degree of cohesion to any society, however heterogeneous it may be. He goes on to argue that defining a notion of coherence that is applicable to complex societies is, however, not an easy proposition: "What can we mean by coherence, in the case of cultures where perspectives diverge and then clash, where people may seek advantage by being different, where groups of people are forever pushing further and further away from the taken for granted in their search for new understandings, where the gains of expertise are suspected to be at the expense of common sense, and where in a division of knowledge specialists prefer to speak to other specialists" (Hannerz,1992). According to Hannerz, a workable notion of coherence must inevitably be based on the assumption that people are, in a sense, able to understand the ideas and the externalised manifestations of ideas of other people. We are concerned here with a perspective that may build bridges to other perspectives. Consequently, according to this author, the level of coherence in a complex society becomes greater as 


\section{GUEST EDITORIAL}

"more people's perspectives make sense of other people's perspectives". This at once implies that diversity is not necessarily synonymous with incoherence. On the other hand, it is clear that achieving coherence is problematic under circumstances of diversity. To Hannerz, coherence is something people need to work at. Concepts such as 'order', 'harmony' and 'sustainable equilibrium' are of little relevance to this coherence notion. The significance of a complex culture, argues Hannerz (1992), stems from a moving interconnectedness.

The fact that democracy seeks to achieve this interconnectedness through procedures and rules of play is not a sign of weakness. Procedures are, in fact, never merely procedures; adherence to them has an educational effect and creates insight into and respect for contentrelated values. Democratic procedures feed the willingness to communicate with each other and thus to make oneself understood. They enhance people's preparedness to exchange ideas and to negotiate. They make the citizen realise that one may dispute anything beyond the rules of conflict, but that the rules themselves must be accepted by all. Consequently, nobody has the final word and no-one can justifiably lay claim to the truth. Therefore the question arises whether democracy, seen from this perspective, does not stand to benefit more from engaging in a struggle for social justice and a more equitable distribution of resources than to focus so hard on multiculturalism as such.

\section{References}

Ahmed, A. (1995). Ethnic cleansing: a metaphor for our time? Ethnic and Racial Studies, 18, 26-45.

Berger, P.L. (1974). Het hemels baldakijn. Bijdrage tot een theoretische godsdienstsociologie. Bilthoven: Ambo.

Berger, P.L. (1992). A Far Glory. The Quest for Faith in an Age of Credulity. Garden City: Anchor Press.

Boender, W. (2001). Multiculturaliteit, burgerschap en Islam in Nederland, in: Naar een Europese islam? Essays, edited by Dick Douwes. Amsterdam: Metz \& Schilt, 2001, 7793.

Brubaker, R. (1990). Immigration, Citizenship and the Nation-State in France and Germany: A comparative Historical Analysis, International Sociology, 5(4):379-407.

Eller, J.D. (1999). From culture to Ethnicity to Conflict. An anthropological Perspective on International Ethnic Conflict. Ann Arbor: The University of Michigan Press.

Enzensberger, H., M. (1993). De grote volksverhuizingen. Amsterdam: De Bezige Bij.

Diner, A. (1998). Nation, Migration and Memory: historical concepts of citizenship, in: Constellations, 4(3): 293-306.

Entzinger, H.B., (1994). De andere grenzen van de verzorgingsstaat. Migratiestromen en migratiebeleid, in: Engbersen, G., Hemerijck, A.C. \& Bakker, W.G. (eds.), Zorgen in het Europese Huis. Verkenningen over de grenzen van nationale verzorgingsstaten (jaarboek 1992/93). Amsterdam: Boom, 142-172.

Foblets, M.-C., Hubeau, B. \& Bouckaert, S. (2001). De opmars van mensenrechten, in: Vranken, J. e.a.(eds.), Komende Generaties. Wat weten we (niet) over allochtonen in Vlaanderen? Leuven: ACCO, 141-165.

Hammar, T. (1990). Democracy and the Nation-state. Aliens, Denizens and Citizens in a World of International Migration. Aldershot: Averbury.

Hannerz, U. (1992). Cultural Complexity. Studies in the Social Organization of Meaning. New York: Columbia Press.

Hjerm, M. (1998). National identity: a comparison of Sweden, Germany and Australia, Journal of Ethnic and Migration Studies, jaargang 24: 451-469. 


\section{GUEST EDITORIAL}

Heisler, M. \& Heisler, B. (1991). Citizenship - Old, New and Changing: Inclusion, Exclusion and Limbo for Ethnic Groups and Migrants in the Modern Democratic State, in: Fijalkowski, J., Merkens H. \& Schmidt, F. (eds.), Dominant National Curltures and Ethnic Minorities. Berlin: Free University of Berlin.

Jacobs, D. (2000). Inburgering. Van integratie naar acculturatie, Ex Tempore. Verleden Tijdschrift Nijmegen, 19(3): 3-13.

Kerkwerk multicultureel samenleven (2001). Opvoeden tot verdraagzaamheid: handleiding voor een gespreksmoment. Brussel: Kerkwerk multicultureel samenleven.

KCM, Integratie(beleid): een werk van lange adem. Deel I: Bakens en eerste voorstellen, Inbel, Brussel, 1989, 34-39; ID (1990), Voor een harmonische samenleving, Inbel Brussel; ID., Eindrapport. Tekenen voor gelijkwaardigheid, Brussel, Inbel, 1993, 5155.

Laermans, R. (1996). Rationalisatie van de leefwereld: secularisatie en kolonisatie, in: Van Hoof, J. \& Van Ruysseveldt, J. (eds.), Sociologie en de moderne samenleving. Heerlen, Open Universiteit: Boom.

Lodewyckx, I. \& Geets, J. (2002). Integratie en Identiteit. een toepassing op de beleving van de Islam, Alert, (28)5: 69-79.

Loobuyck, P. (2000). Inburgeren in Nederland en Vlaanderen. Een inleiding tot een debat, $\begin{array}{llll}\text { Samenleving en } & \text { Politiek, } & \text { 21-35): }\end{array}$ (http://www.flwi.ugent.be/cie/CIE/loobuyck4.htm).

Loobuyck, P. (2001a). Vreemdelingen over de (werk)vloer: het debat over arbeidsmigratie en de migratiestop in kaart. Gent : Academia Press.

Loobuyck, P. (2001b). Migratie: pleidooi voor een creatief debat, Streven, (68)7: 623-633.

Loobuyck, P. (2002). Multicultureel burgerschap: voorbij integratie, assimilatie, segregatie en $\begin{array}{llll}\text { marginalisering, } & \text { Ons } & \text { Erfdeel, } & \text { 35(3): }\end{array}$ (http://www.flwi.rug.ac.be/cie/CIE/loobuyck2.htm).

Loobuyck, P. (2003a). Het Vlaams minderhedenbeleid. Een status quaestionis, Migrantenrecht, 17(3): 84-88.

Loobuyck, P. (2003b). Vlaanderen, België en Europa als immigratiesamenlevingen. Enkele consequenties, Streven, 70(8): 715-727.

Luckmann, T. (1967). The Invisible Religion. The Problem of Religion in Modern Society. New York: Macmillan.

Marshall, T. (1963). Sociology at the Crossroads and other essays. London: Heineman.

Nuhoglu-Soysal, Y. (1997). Changing parameters of citizenship and claims-making: organized Islam in European public spheres, Theory and Society, jaargang 26: 509-527.

Roosens, E. (1998). Eigen grond eerst? Primordiale autochtonie. Dilemma van de multiculturele samenleving. Leuven: ACCO.

Seifert, W. (1997). Admission policy, patterns of migration and integration: the German and French case compared, New Community, jaargang 23: 441-460.

Stewart, A. (1995). Two conceptions of citizenship, British Journal of Sociology, 46(1): 6378.

Timmerman, C. (2003). Cultuurrelativisme: realiteit of fictie? Migratie en etnische minderheden in België (OASeS Document 1). Antwerpen / Apeldoorn: Garant.

Timmerman, C. e.a. (1999). Integratie van tweede generatie migrantenvrouwen in Vlaanderen: verschillende wegen tot integratie. Antwerpen: UFSIA - CASUM.

Van den Bossche, G. \& Zemni, S. (2002). Allochtonen aller landen... burger u in, in: Van den Brande, A. (ed.), Identiteiten. Functies en disfuncties. Gent: Academia Press, 107-143.

Vermeulen, H. e.a. (1997). Immigrantenbeleid voor de multiculturele samenleving: integratie, taal- en religiebeleid voor immigranten in vijf West-Europese landen. Amsterdam: Imes. 


\section{GUEST EDITORIAL}

Wets, J. (ed.) (2001). Migratie en asiel: vluchten kan niet meer. Syntheserapport van een onderzoeksproject inzake het migratie- en asielbeleid in België. Brussel: Koning Boudewijnstichting.

Wimmer, A. (1997). Explaining xenophobia and racism: a critical review of current research approaches, Ethnic and Racial Studies, jaargang 20: 17-41. 